\title{
Pytania egzystencjalne we wczesnej edukacji religijnej
}

\section{Summary}

\section{Existential questions in (early) religious education}

The dispute on the possibility and shape of teaching religion in the public school has been going on for centuries. And although this education has found its place in school, the debate that is around them means that in the face of the challenges of pluralism, multiculturalism and multi-religiousness, it must constantly determine its status, mission, goals and tasks. There are still numerous doubts as to whether the school is at all the most appropriate place for shaping the sensitive areas of the human spirit, which is the religious worldview. The purpose of this text is to reflect on the place and role of existential questions in (Polish) early religious education. The text also asks about the dialogical nature of teaching, which is a cardinal prerequisite for philosophical inquiry in education (including religious education). For the purpose of this study, the analysis of "Basic Program of the Catechesis of the Catholic Church in Poland" from 2010 and 2018 was made.

Keywords: religious education of children, children's existential questions

Słowa kluczowe: edukacja religijna dzieci, dziecięce pytania egzystencjalne

Od ponad 300 lat toczą się w Europie dyskusje na temat edukacji religijnej w szkole. Mimo że odnalazła ona w niej swoje miejsce, w obliczu wyzwań wielokulturowości i wieloreligijności na nowo musi określać swój status, misję, zadania, treści i warsztat metodyczny. Celem niniejszego artykułu jest namysł nad stosunkiem do pytań egzystencjalnych i ich roli we wczesnej edukacji religijnej, nie tylko w Polsce, ale i w innych krajach.

Pejzaż edukacji religijnej w europejskich systemach szkolnych porządkują klasyfikacje Flavio Pajera, Jana Charytańskiego i Rapha Sauera. Pierwszy proponuje, by religię wyróżnić jako przedmiot obowiązkowy, fakultatywny, pozaprogramowy lub pozaszkolny (Pajer 1992: 393). Drugi autor różnicuje nauczanie religii na szkolne konfesyjne i niekonfesyjne oraz pozaszkolne (Charytański 1992: 196). Trzeci badacz zaś bierze pod uwagę charakter religii jako przedmiotu konfesyjnego bądź niekonfesyjnego i jej status jako przedmiotu obowiązkowego, dobrowolnego bądź pozaszkolnego (Sauer 2000: 292-295).

W charakterystykach edukacji religijnej uwzględnia się również inne kryteria:

- podmiot, który ją organizuje i czuwa nad nią;

- adresatów, do których jest ona kierowana; 
- godziny alternatywne (fakultatywne/obligatoryjne) lub ich brak;

- tygodniową liczbę godzin lekcji religii dla kolejnych poziomów edukacji;

- rolę, status i oczekiwania wobec nauczycieli religii (Sauer 2000: 292-295; Chałupniak 2005: 35).

W większości państw europejskich - poza Francją, Białorusią, Bułgarią i Rosją - nauczanie religii odbywa się w obrębie systemu szkolnictwa publicznego, choć status tych lekcji jest różny. Religia bywa w szkołach publicznych przedmiotem obowiązkowym, niezależnie od tego, czy dane państwo uznaje jedno z wyznań za religię państwową, czy też nie. Występuje też ona jako przedmiot fakultatywny (komplementarnie z innymi przedmiotami zainteresowanymi kształtowaniem wiedzy na temat religii, wartości i norm bądź światopoglądu) (Mąkosa 2011: 123-136).

W Polsce religia jest konfesyjnym przedmiotem nadobowiązkowym i fakultatywnym. Rodzice lub uczniowie (po ukończeniu 18. r.ż.) mogą dokonać wyboru między religią i etyką (lub nie wybrać żadnego z tych przedmiotów). Lekcje etyki są prowadzone jednak $\mathrm{w}$ nielicznych polskich szkołach, co w praktyce oznacza brak wspomnianej alternatywy (Mąkosa 2011: 123-136).

\section{Edukacja religijna - portret wnętrza}

Interesujący obraz edukacji religijnej powstaje, gdy w centrum namysłu nad nią postawimy religię jako część kultury bądź jako byt samoistny. Pozwala to wyodrębnić dwie odmienne wizje edukacji religijnej. Pierwsza proponuje jej rozumienie kontekstowe, druga rozumienie istotowe (Gunnarsson 2018: 70). Stanowisko kontekstowe akcentuje wage studiowania religii przez uczniów w pełnym kontekście zróżnicowania kulturowego oraz rolę, jaką odgrywają w tym zakresie osobista wiedza i doświadczenia ucznia (Jackson 2004: 87-108). Stanowisko istotowe dowodzi, że wyłącznie kontekstowe (horyzontalne) rozumienie edukacji religijnej prowadzi do jej zbyt wąskiej interpretacji antropologicznej, co redukuje religię do wymiaru kulturowego i przesłania jej wymiar wertykalny, który uwzględnia kwestie transcendencji i prawdy ostatecznej, stanowiące jej istotę i główny cel. Dlatego każde studium religii, które się do nich nie odnosi (niezależnie od konkluzji i wniosków, do których prowadzi), jest redukujące (Wright 2008: 3-12). Religia ujmowana istotowo z natury rzeczy jest też kontekstowa, gdyż funkcjonuje w narzuconych ramach historycznych, kulturowych i intelektualnych, jednak w szkolnych programach nauczania powinna być wiązana $\mathrm{z}$ jej nieodłącznym znaczeniem, tj. zdolnością do udostępniania faktycznego porządku rzeczy (Wright 2004: 208-222).

Edukacja religijna ma prowadzić do transformacji życia uczniów przez uwolnienie ich od wąskiego horyzontu nowoczesności i otwarcie na religijne rozumienie siebie, innych i świata. Jej zadania to umożliwienie przekazywania uczniom - zaczynając od najmłodszych - wiedzy, wierzeń, wartości i postaw; pomaganie im w formułowaniu uzasadnionych stanowisk religijnych roszczeń prawdy i rozwijanie umiejętności myślenia, działania i komunikowania się, trzeba przy tym mieć na względzie pluralizm wspomnianych roszczeń (Wright 2004: 208-222). 
Jackson (2004) ostrzega przed niebezpieczeństwem prezentowania światopoglądów religijnych jako zamkniętych systemów wiary. Krytykuje propozycję Wrighta za jej zbyt intelektualne podejście do edukacji religijnej i zbyt wielką wagę, jaką przywiązuje ona do racjonalizmu. Zarzuca jej prawie całkowite wykluczenie z edukacji religijnej dziecięcych uczuć i emocji i proponuje elastyczny, osobisty model, uwzględniający indywidualność i wyjątkowość każdego dziecka (Jackson 2004: 87-108).

Autor ten podkreśla znaczenie (,," i „dla” edukacji religijnej) wewnętrznej różnorodności tradycji religijnych, ich (często opozycyjnego, spornego) wspótistnienia i towarzyszącą mu złożoność ekspresji i zmian kulturowych, opartych na perspektywie społecznej i indywidualnej. Jako przykład podaje różnorodność religijną wśród dzieci z rodzin chrześcijańskich (Jackson 2004: 87-108).

Przyjmując, że edukacja religijna obejmuje rozumienie światopoglądów innych, konieczne jest uwzględnienie w jej treściach bogactwa zagadnień dotyczących reprezentacji materiału religijnego i jego interpretacji. Jej zasadniczym celem jest pomoc uczniom $\mathrm{w}$ znalezieniu własnego stanowiska, pozycji w dyskusji przez prezentowanie pluralizmu religijnego, w nabyciu kompetencji rozumienia różnych tradycji religijnych i sposobów życia itp. Jackson podkreśla, że własne doświadczenia, przemyślenia, pytania, emocje uczniów powinny być bezpośrednio wykorzystywane w edukacji religijnej. Tam gdzie interpretacja wymaga od ucznia porównywania rozumianych już przezeń koncepcji i idei z nowymi, perspektywa dziecka może stanowić ważną część procesu edukacyjnego (Jackson 2004: 87-108). Na jego treści składają się wówczas nie tylko informacje uzyskane wprost od nauczyciela czy z podręcznika, ale także wiedza i osobiste doświadczenia dziecka (Jackson 2004: 87-108).

Zdaniem Jacksona nauczyciel religii powinien posiadać umiejętności sprzyjające nauczaniu dialogicznemu. Gdy nauczyciel dysponuje odpowiednią wrażliwością (w stosunku do własnego stanowiska i poglądów uczniów), może kreować taką edukację religijną, której istotą jest dyskusja radząca sobie z napotkaną różnorodnością. Stwarza to też możliwość pogłębienia przez dzieci własnych poglądów przez badanie stanowisk innych związanych z nimi tradycji oraz możliwość wykorzystania krytycznych i twórczych zdolności do uczenia się. Powstaje swego rodzaju „poligon”, na którym mogą one testować różne sposoby myślenia i interpretowania rzeczywistości. W ten sposób własne doświadczenia religijno-kulturowe, refleksje i interakcje uczniów stają się immanentną częścią edukacji religijnej (Jackson 2004: 87-108).

W tej optyce osadzone jest stanowisko europejskiej debaty na temat edukacji religijnej, wsparte argumentacją opartą na prawach człowieka. Zgodnie z nim świeckie poglądy na świat powinny być szanowane na równi z poglądami religijnymi i stanowić integralną część edukacji religijnej (Hovde Bråten 2018: 157). Integrację światopoglądów religijnych i niereligijnych w ramach tej edukacji uważa się za największe wyzwanie stojące obecnie przed szkołą (Jackson 2014: 139).

Rosnącą popularnością cieszy się idea nauczania „interreligijnego”, której uzasadnień poszukuje się w coraz silniej dającym o sobie znać pluralizmie religijnymi światopoglą- 
dowym oraz konieczności pokojowego współistnienia różnych religii i światopoglądów. W sytuacji gdy do tej samej klasy coraz częściej uczęszczają dzieci różnych wyznań chrześcijańskich, wyznawcy judaizmu, islamu czy ateiści, znaczenia nabiera oferta edukacji religijnej, która może być adresowana do grupy silnie zróżnicowanej religijnie (Mąkosa 2011: 133). Jej głównym celem jest poznawanie innych religii i kultywowanie dialogu między różnymi wyznaniami, co prowadzi do wzrostu tolerancji i pokojowego współżycia ludzi o różnych afiliacjach religijnych (Sterkens 2001: 63-64; Mąkosa 2011: 133). Pluralizm oznacza wartość i szansę dialogu w poszukiwaniu odpowiedzi, wzajemnego wzbogacania i uświadamiania sobie tego, co łączy lub dzieli. Wzmacnia to równocześnie uczniowską przynależność wyznaniową, a doświadczenie pluralizmu wspiera dzieci w internalizacji i pogłębianiu własnej wiary. Warunkiem powodzenia takiej edukacji religijnej jest jednak dojrzała tożsamość wyznaniowa uczniów, co sprawia, że nie wszystkie dzieci mogą z niej korzystać (Sterkens 2001: 63-64).

Przywołane stanowiska, mimo różnic w rozumieniu religii i edukacji religijnej, dość jednomyślnie podkreślają wagę własnych doświadczeń religijnych i światopoglądowych uczniów. Religia powinna być dostępna dla wszystkich dzieci, niezależnie od ich afiliacji religijnej czy religijnego bądź świeckiego poglądu na życie. Ważne, by uznawała pluralizm jako istotną jakość wpisaną w rzeczywistość oraz by podkreślała wagę otwartości i elastyczności w kontaktach $\mathrm{z}$ tą różnorodnością. Wielu badaczy akcentuje też ważną rolę, jaką w tej edukacji odgrywają dziecięce pytania egzystencjalne.

\section{Dziecięce pytania egzystencjalne a edukacja religijna}

Pytania egzystencjalne z racji swojego charakteru i zakresu bywają też określane mianem pytań filozoficznych (Hartman 1986: 20). Pytania te dotyczą początków wszechrzeczy, istnienia Boga, wiary, człowieka i świata, dzieci interesują się sensem i celem ludzkiego życia, kruchością bytu, przemijaniem, śmiercią czy istnieniem moralnego dobra i zła. Zróżnicowanie formy tych pytań jest świadectwem wysiłku podejmowanego przez człowieka w celu ich zrozumienia i zinterpretowania (Hartman 1986: 20); stanowi wyraz jego indywidualnej potrzeby porządkowania wyników doświadczania siebie i „świata”, budowania wartości własnych rozumowań itp. Dzięki nim człowiek dociera do istoty wszelkich pytań filozoficznych. Podejmowane w tym celu wysiłki mają charakter procesu całożyciowego i dotyczą też najmłodszych (Hartman 1986: 20-21). Choć w wypadku różnych osób odmienne są sposoby badania, stopień abstrakcji czy zewnętrzne ramy odniesienia, to można też wskazać punkty wspólne: ludzie rodzą się, żyją i umierają - i to definiuje stawiane przez nich pytania egzystencjalne.

Również według Lipmana i in. (1997) dziecięce zapytywanie kieruje się w stronę rozumienia i sensu. Dzieci, podobnie jak dorośli, wiedzą, czym jest poczucie braku sensu, odbierane jako doświadczenie bardziej niepokojące i przerażające niż zwykłe odczucie zagadkowości. Boleśniej niż dorośli odczuwają, czym jest doświadczenie niewypełnione sensem i nie pozostają bierne wobec tego braku. Aktywnie poszukują tego, co wypełni ich 
doświadczenia znaczeniem (Lipman 1997: 30). Stawiane przez nie pytania są dowodem nieustającej otwartości na pojawiające się nieznane. Odpowiedzi szukają w wyjaśnieniach naukowych, symbolicznych oraz - co zdaniem Lipmana najważniejsze - filozoficznych. Wiele dziecięcych pytań dotyka złożonych kwestii o charakterze metafizycznym, logicznym czy etycznym (Lipman 1997: 53-55). Mimo że dzieci, zwłaszcza młodsze, nie dysponują jeszcze w pełni ukształtowanym układem odniesienia dla swoich życiowych doświadczeń, podejmują próby rozpoznawania tego, co jest dla nich niezrozumiałe. Zapytują o okoliczności umożliwiające wyjaśnienie „niezrozumiałego” i nadanie mu sensu. Motywowane niedostatkiem wiedzy, rozumienia i pewności - wyrażają wątpliwości, pytają, domagają się wyjaśnień. Jedną z istotnych płaszczyzn, których dziecięce wątpliwości i pytania, jest religia.

Już William Stern, obserwując własne dzieci, dostrzegł, jak szybko postawiły one pytanie o pochodzenie wszystkiego, co istnieje - $\mathrm{w}$ tym także bytu ponadnaturalnego, jakim jest Bóg. Systematycznie odkrywały, że wszystko wokół nich musiało kiedyś powstać i że Bóg nie jest wyjątkiem od tej reguły. Formułowanie uniwersalnych pytań dotyczących Boga Stern uznał za jeden z ulubionych motywów dziecięcych poszukiwań filozoficznych (por. Stern 1957). Jego spostrzeżenia wskazują, że nawet przedszkolakom nieobce są dociekania w przestrzeni religijnej, czego przykładem może być pytanie współczesnego czterolatka: Mamo, a wiesz, że Pan Bóg jest świattem? Tylko chyba nie takim w lampie... tylko w księżycu.

\section{Dziecięce pytania egzystencjalne a edukacja religijna - przykład szwedzki}

Aby wskazać miejsce dziecięcych pytań egzystencjalnych w edukacji religijnej, odwołam się do Szwecji, gdzie w centrum myślenia na jej temat postawiono dziecko: jego uczucia, doświadczenia, formułowane przezeń pytania egzystencjalne (Hartman, Petterson 1980). Stały się one nie tylko ważną częścią, lecz przede wszystkim podstawą kolejnych reform edukacji religijnej, już bowiem w latach 60 . dostrzeżono ich istotny potencjał edukacyjny i podjęto wysiłek wykorzystania go w praktyce (Hartman 2018: 23).

W latach 60. rozpoczęto cykliczne badania nad pytaniami egzystencjalnymi i filozofią życia dzieci i nastolatków. Wykazały one, że badani - niezależnie od wieku - poszukiwali odpowiedzi na pytania filozoficzne dotyczące rasy, seksualności, miłości, cierpienia, wartości i norm, wolności, odpowiedzialności, winy i kary, zaufania, samotności i wspólnoty, dobra i zła itp. Chociaż pytania dotyczące Boga, religii i wiary należały do rzadziej zadawanych, uczniowie oczekiwali możliwości dyskutowania o nich na lekcjach religii (Gunnarsson 2018: 73). Badania wśród młodszych dzieci wykazały, że pytania egzystencjalne są dla nich ważne, a wątpliwości, zapytywanie i kontestacja są charakterystyczne także dla tej grupy wiekowej, a nie tylko dla młodzieży (Hartman i in. 1973; Ekström, Odencrants 1980). Wyniki badań z lat 1979-1980 (Hasselrot, Lernberg 1980) potwierdziły te tendencje (Gunnarsson 2018: 73-74).

Wcześniejszy szwedzki program nauczania religii dla szkół powszechnych (Lgr 62 1962) koncentrował się na przedmiocie „wiedza chrześcijańska”, gdzie nacisk kładziono 
na „obiektywność”. Budziło to liczne kontrowersje, gdyż nie określono dostatecznie wyraźnie, jak rozumieć ten kluczowy wymóg. Nauczyciele nie byli pewni, jak uczyć religii (Hartman 2000: 212-251). Po wspomnianym cyklu badań akcent przeniesiono z obiektywności na (pytania) ucznia. Zmieniono też nazwę przedmiotu „edukacja religijna” na „life-question education”. Curriculum zaś skonstruowano wokół uczniowskich pytań egzystencjalnych i dziecięcej filozofii życia (Lgr 69 1969). Life questions zostały wprowadzone na stałe do programu nauczania religii dla szkół powszechnych. W nowym curriculum (Lgr 80 1980) mocniej zaakcentowano natomiast problematykę życia, w curriculum w latach 90. zaś nauczanie o życiu zastąpiono jego interpretacją (Lpo 94 1994), którą określono terminem: „,wiara i poglądy na problemy życiowe”. Akcenty przesunięto na wiedzę i refleksję obejmującą różne religie i poglądy na temat życia. Wspomniana wcześniej perspektywa dziecka nadal tworzyła centralną oś szwedzkiej edukacji religijnej, co postrzegano jako szansę na realizację jednego z jej najważniejszych celów: pomocy dzieciom w pogłębianiu własnych doświadczeń egzystencjalnych i wiedzy, w poszerzaniu ram odniesienia oraz zachęcaniu do refleksji nad ważnymi kwestiami życia i etyczności (Gunnarsson 2018: 74).

Daleko idąca poprawność polityczna oraz pluralizm religijny i światopoglądowy (sprzężone z polityką Szwecji wobec emigrantów) wymusiły wypracowanie podejścia, które oferuje uczniom wsparcie $\mathrm{w}$ radzeniu sobie $\mathrm{z}$ wielością i różnorodnością. $\mathrm{W}$ propozycjach edukacji religijnej podkreślano znaczenie refleksji na temat różnych poglądów religijnych, kulturowych czy filozoficznych i prawa do prezentowania w szkole odmiennych perspektyw i postaw religijnych $\mathrm{i}$ areligijnych, mających podłoże $\mathrm{w}$ określonym wyznaniu, w obyczajach własnej rodziny czy społeczności, z której się pochodzi (Jackson 2004: 165; Gunnarsson 2018: 74).

Trajektoria szwedzkich reform edukacji religijnej jest przykładem rozwiązań, które od końca lat 60. niezmiennie w centrum stawiały dziecko i jego pytania egzystencjalne. Podstawą przemian było założenie, że uczniowie (niezależnie od wieku) są zdolni do osobistego odniesienia do religii i związanych z nią przekonań. Stworzono warunki do refleksji nad tożsamością (religijną), do rozwijania osobistego stosunku do życia oraz rozumienia własnego sposobu myślenia, a także myślenia i życia innych ludzi. We wczesnej edukacji oczekuje się, że uczniowie podejmą namysł nad podstawowymi kwestiami życiowymi; w klasach starszych - zaangażują się w dialog, którego istotę stanowić będzie deskrypcja, porównywanie i analiza odmiennych sposobów życia w różnych religiach i z różnymi przekonaniami (Gunnarsson 2018: 75). Pytanie o edukację religijną w Szwecji dotyczy dzisiaj zatem nie tego, CZY wykorzystywać filozoficzne pytania dzieci, lecz JAK nad tymi pytaniami pracować z uczniami w różnym wieku.

Obraz szwedzkiej edukacji religijnej nie byłby pełny, gdyby pominąć tu słabości, jakie dostrzegają jej krytycy. Najpoważniejszy zarzut wskazuje, że w praktyce szkolnej często nadal dominuje hegemoniczna ideologia świecka, w której najważniejszą rolę odgrywa czerpanie z „obiektywności” i „światopoglądu”. Religia występuje tu jako opozycyjna w stosunku do nich, co wywołuje u uczniów, zwłaszcza młodszych, obawy przed ujawnia- 
niem własnych stanowisk religijnych (Kittelmann Flensner 2015). Choć pytania egzystencjalne stanowią w Szwecji co do założeń immanentną część edukacji religijnej, jej krytycy wskazują na istnienie poważnej luki między założeniami a praktyką w tym zakresie (Risenfors 2018: 119-136). Dowodzi to, jak trudno wprowadzić pytania egzystencjalne w praktyce; wskazuje też na prawne i edukacyjne wyzwania w zakresie łączenia edukacji religijnej dla wszystkich z szacunkiem dla osobistych przekonań tych, którzy są w nią zaangażowani.

\section{Pytania egzystencjalne - nieobecny wymiar w polskiej edukacji religijnej}

Na przełomie lat 1990-1991 katecheza po długiej przerwie wróciła do polskiej szkoły. Aktualna Podstawa programowa katechezy Kościoła katolickiego w Polsce (KEP 2010), zawierająca ścisłe wskazania, które określają specyfikę nauki religii prowadzonej przez Kościół, zobowiązuje, by w katechezie przestrzegać „podwójnej zasady wierności” (Bogu i człowiekowi). Akcentuje zarówno osobę Chrystusa (w jego wymiarze historycznym), tajemnicę zmartwychwstania (centrum życia człowieka i świata), jak i tajemnicę Kościoła. Wspomina o znaczeniu potrzeb i możliwości percepcyjnych uczniów i - co należy podkreślić - o znaczeniu egzystencjalnych pytań, które mogą się aktualizować się jedynie w warunkach dialogu. Należy więc zapytać o konieczne i wystarczające warunki i możliwości dialogu w szkole - z naciskiem na praktykę katechetyczną rzymskiego katolicyzmu, której głównym celem jest przekaz Prawdy Objawionej.

Badania nad szkołą (Klus-Stańska 2008; Szczepska-Pustkowska 2008; Śliwerski 2010) pokazują, że nie jest ona pod żadnym względem zainteresowana rozwijaniem dialogiczności w nauczaniu ani pielęgnowaniem dziecięcych przejawów (filozoficznego) namysłu nad światem. Dowodzą też, że nauczyciele, mimo świadomości znaczenia dialogu, preferują adialogiczny, transmisyjny, odtwórczy model pracy z uczniami, w którym dominują metody oparte na monologu, dostarczające dzieciom zunifikowanych znaczeń do reprodukcji. Mitologia transmisji mocno „wczepiona” jest w styl pracy szkoły (Klus-Stańska 2008: 35-45), której główną słabością jest skrajna unifikacja obecnych w niej dopuszczalnych sposobów myślenia, co ogranicza udział ucznia we współtworzeniu wiedzy. Analiza praktyk wczesnoszkolnych pod kątem ich zdolności do rezygnacji z transmisji wiedzy uznanej za jedyną poprawną na rzecz kreowania warunków jej aktywnego współkonstruowania przez dzieci ujawnia przewagę wiedzy przyswajanej „po śladzie” nauczyciela nad wiedzą konstruowaną , w poszukiwania śladu” (Klus-Stańska 2002: 229236). W wypadku religii ma to dodatkowe znaczenie wynikające $z$ konfesyjnego charakteru przedmiotu, którego zadaniem jest ,ubogacać i poszerzać horyzonty poznawcze człowieka”, wprowadzając "nowy rodzaj poznania, nazywanego "poznaniem religijnym«" (Marek 2017: 20-21). Edukacja religijna to proces oparty na źródłach religijnych, które łączy objawienie Boże i ludzkie doświadczenie (Marek 2017: 20-21). Lekcje religii służą uprawianiu i uprawomocnianiu ,teologii zstępującej prawdy objawionej” (Bartoś 2008: 76-77). Chodzi tu o przekaz podstawowych prawd wiary w sposób nie tyle prawdziwy, ile przede wszystkim zobowiązujący. 
Dialog z teologią zstępującą, której efektem jest myślenie kategoriami „parametrów religijności”, jest niezwykle trudny (Mąkosa 2009). Tworzą one kanon oceny zgodności kondycji religijno-moralnej wychowanka z założonym ideałem wychowania. $\mathrm{W}$ wypadku koncepcji doktryny „prawdziwej” nie ma miejsca na dziecięce wątpliwości i pytania - nawet wówczas, gdy katecheta ma świadomość wartości dialogu. Podążanie „przed dzieckiem" jest ogólną zasadą przenikającą nie tylko lekcje religii, lecz całą szkołę, w której uczeń zdobywa wiedzę, poruszając się „po śladzie” nauczyciela. W szkole chorobliwie przywiązanej do nauczycielskiego monologu i wizji dziecka cierpliwie uczestniczącego w transmisji wiedzy nie sposób rozwijać i pielęgnować pogłębioną refleksję - także religijną - i dialog.

Nowa Podstawa programowa Kościoła katolickiego w Polsce (KEP 2018), która (wraz z podręcznikami) będzie stopniowo wprowadzana od września 2020 do września 2023 roku, nie zmienia tej sytuacji. Przeciwnie - zawiera precyzyjny zapis wiedzy, umiejętności i kompetencji społeczno-moralnych, które dzieci mają opanować w przedszkolu i w ciągu kolejnych lat nauki. Treści tego dokumentu niewiele mają wspólnego z zachętą do krytycznej dyskusji. Zalecają natomiast systematyczne kształtowanie przekonań i postaw uczniów, formowanie „tożsamości kościelnej” wyznawcy religii katolickiej o ugruntowanych poglądach. Akcentują wagę posłuszeństwa dziecka wobec Kościoła i jego nauk, jego aktywnego wspierania i obrony, podejmowania działań apostolskich i kształtowania odporności na poglądy świeckie. Misją edukacji religijnej jest rozbudzenie silnej emocjonalności religijnej, krzewienie żarliwej religijności i formacja osobowości uczniów przez naukę o zwalczaniu własnej grzesznej natury (KEP 2018: 44).

Podstawa przyjęła nowy podział edukacyjny, który składa się z 3 etapów edukacji religijnej, z których każdy obejmuje 4 klasy: przedszkole, wczesną edukację (I-IV), edukację na poziomie klas V-VIII oraz edukację na poziomie szkoły ponadpodstawowej. W przedszkolu celem prowadzonych zajęć jest budowanie pełnej zaufania relacji z osobowym Bogiem, zapoznanie z Chrystusem, ,ukazanie Maryi w dziele zbawienia” i świętych ,jako przyjaciół Pana Boga” (KEP 2018: 21). Już pięciolatek powinien rozumieć, ,że przez chrzest staje się dzieckiem Bożym” (KEP 2018: 22) i dostrzegać „dary Bożej miłości objawiającej się przez stworzenie i odkupienie" (KEP 2018: 21), co staje się możliwe dzięki katechezie. Przedszkolak ma kochać Boga, Chrystusa i bliźnich, ma nauczyć się oceniać swoje zachowanie w świetle przykazania miłości (KEP 2018: 22).

Klasy I-IV obejmują katechezę, której celem jest przygotowanie dzieci do pierwszej komunii i etapu pokomunijnego. Nacisk kładzie się na wdrażanie do częstej spowiedzi i komunii. Słowem kluczem jest tu „posłuszeństwo”; Podstawa wskazuje bowiem, że dziecko w wieku 7-11 lat powinno być „posłuszne natchnieniom Ducha Świętego”, „okazywać wdzięczność Jezusowi”, „troszczyć się o życie w stanie łaski uświęcającej” i „starać się żyć w postawie czujnego oczekiwania na powtórne przyjście Pana” (KEP 2018: 33). Uczeń powinien wyrażać pragnienie „świadomego i głębokiego zjednoczenia z Chrystusem Eucharystycznym", ufać Bogu i go naśladować (KEP 2018: 38). Podstawa zaleca, by dziecko przyjęło „prawdę, że owoc modlitwy zależy od woli Boga”, oraz 
podporząadkowało się tej woli (KEP 2018: 39). Nacisk kładzie się na uczestnictwo ucznia w liturgii i systematyczne kontrolowanie, czy potrafi on „wyjaśnić sens praktykowania pierwszych piątków miesiąca”, ,należycie przygotować się” do mszy, spowiedzi, komunii itp. Oczekuje się, że dziecko zrozumie, że „Eucharystia jest ofiarą Chrystusa i Kościoła” i że zostało do niej dopuszczone dzięki katechezie (KEP 2018: 36). Etap wczesnej edukacji religijnej postrzegany jest jako kluczowy dla budowania „tożsamości kościelnej” (której niezbywalnym elementem jest życie ze świadomością grzechu, żal za grzechy, troska o własne zbawienie, przekonane o potrzebie regularnej pracy nad sobą i decyzja o przemianie własnego życia) (KEP 2018: 36). Już ten krótki rys programowy wskazuje, że na dziecięce pytania egzystencjalne i dociekania nie ma tu miejsca.

W klasach V-VIII edukacja religijna obejmuje intensywne przygotowania do sakramentu bierzmowania, których centrum stanowi mistagogia. W szkole ponadpodstawowej oś przewodnią katechezy tworzy wychowanie do dorosłości chrześcijańskiej, kształtowanie tożsamości kościelnej, przygotowanie do działań apostolskich (apologia wiary) i „trud samowychowania" (KEP 2018: 109). Formacja moralna jako część edukacji religijnej akcentuje „świadomość własnej grzeszności” (KEP 2018: 111), wskazując jej źródła tkwiące w zagrożeniach obecnych w świecie (,,konsumpcjonizm”, „seksualność”, „ideologia gender" itp.) (KEP 2018: 108-113). Dorastający uczeń ma odpowiedzialnie kształtować swoją seksualność jako dar Boży (KEP 2018: 102), troszczyć się o „czystość serca”, cenić „czystość i jej wartość przed małżeństwem i w małżeństwie” (KEP 2018: 113). Na tym etapie także nie ma miejsca na samodzielną uczniowską refleksję.

Teksty biblijne i nauczanie Kościoła postrzega się w trakcie całej edukacji religijnej jako bezdyskusyjne źródło dające odpowiedzi na wszelkie uczniowskie rozterki, wątpliwości i pytania egzystencjalne (KEP 2018: 99-100). Uczeń od najwcześniejszego etapu edukacji ma poszukiwać odpowiedzi, zgłębiając Słowo Boże. Aktywność uczniów zostaje ograniczona do biernego, bezrefleksyjnego przyswajania zunifikowanych i bezdyskusyjnych, bo dogmatycznych, treści objawionych. Dociekanie nie jest obecne w edukacji religijnej, gdyż nacisk kładzie się na to, by uczeń nauczył się, co myśleć, a nie - jak myśleć.

$\mathrm{Na}$ lekcjach religii otwarta, refleksyjna, pytajna postawa dzieci wobec rzeczywistości (religijnej) zostaje zawieszona jako nieprawomocna i zbędna. Pod uwagę nie są też brane osobiste doświadczenia kulturowo-religijne dziecka. Przekazywana dzieciom wiedza religijna zostaje oddzielona od myślenia i doświadczenia, pozostaje natomiast w silnej relacji z dogmatami wiary. Tak zdefiniowana edukacja religijna raczej uśmierca niż pielęgnuje dziecięcą pytajność, czyniąc z ucznia przedmiot religijnej „obróbki”.

Mimo deklaracji w obu podstawach programowych edukacja religijna w Polsce nie bierze także pod uwagę znaczenia, wynikającego z różnorodności tradycji religijnych. Pluralizm, którego celem - w odniesieniu do zasady dialogu - jest jednoczenie społeczności, budowanie otwartości i elastyczności w kontaktach z odmiennością i wielością, poddaje się krytyce jako uciążliwą ułomność. Uznaje się go za dobry jedynie wtedy, gdy w grę wchodzą kwestie błahe, a gdy różnorodność, odmienność i wielość wymaga odstępstw od wartości podstawowych, traktuje się go jako niepożądane ustępstwo. Ograniczony plu- 
ralizm został uznany jedynie w odniesieniu do wyboru podręczników, co uzasadniono zróżnicowaną sytuacją religijną w różnych rejonach Polski (KEP 2018).

Treści przekazywane uczniom na lekcjach religii były, są - i jak wynika z nowej Podstawy - nadal będą podporządkowane teologii zstępującej prawdy objawionej, a wynikająca stąd formuła zajęć nie przewiduje dyskusji ani w przestrzeni religijnej, ani tym bardziej w świeckiej. Lekcje katechezy nie pozostawiają uczniom miejsca na jakiekolwiek wątpliwości, dociekania czy pytania egzystencjalne. Dzieciom wpaja się przeświadczenie, że Bóg nie jest po to, by o niego pytać, czy o nim dyskutować, lecz by w niego wierzyć. Edukacja religijna w Polsce pozostaje niestety przestrzenią pozbawioną dziecięcego „dlaczego"?

\section{Literatura}

Bartoś T. (2008), Jan Pawet II. Analiza krytyczna. Warszawa, Sic!

Chałupniak R. (2005), Między katecheza a religioznawstwem. Nauczanie religii katolickiejw szkole publicznej w Niemczech $w$ latach 1945-2000. Opole, WT UO.

Charytański J. (1992), Lekcje religii w Europie. „Ateneum Kapłańskie”, 498.

Ekström U., Odencrants J. (1980), Livsfrågor och attityder hos barn i åldrarna 9-13 år. Stockholm, Högskolan för lärarutbildning, Institutionen för pedagogik.

Gunnarsson G.G. (2018), Is a »life question approach « appropriate when religious education has become a part of social studies? W: J. Ristiniemi, G. Skeie, K. Sporre (eds.), Challenging life existential questions as a resource for education. Münster-New York, Waxmann.

Hartman S.G. (1986), Children's philosophy of life. Stockholm, Institute of Education, Department of Educational Research.

Hartman S.G. (2000), Hur religionsämnet formades. W: Almén E., Furenhed R., Hartman S.G. Livstolkning och värdegrund: att undervisa om religion. Linköping, Linköping University.

Hartman S.G. (2018), Children Searching for a Philosophy of Life. W: J. Ristiniemi, G. Skeie, K. Sporre (eds.), Challenging life existential questions as a resource for education. MünsterNew York, Waxmann.

Hartman S.G., Petterson S. (1980), Livsfrågor och livsåskådning hos barn: någrautgångspunkter för enanalys av barns livsfrågor och livsåskådning samt en presentation av några delstudier inom området. Rapport 7. Stockholm: Högskolan för lärarutbildning, Institutionen för pedagogik.

Hartman S.G., Petterson S., Westling G. (1973), Vadfunderar barn på? Stockholm, Utbildningsforskning.

Hasselrot T., Lernberg L.O. (ed.) (1980), Tonåringen och livet: undersökning och diskussion kring tonåringen och livsfrågorna. Stockholm, Liber Utbildningsförlaget.

Hovde Bråten O.M. (2018), World Views in Norwegian RE. W: J. Ristiniemi, G. Skeie, K. Sporre (eds.), Challenging life existential questions as a resource for education. Münster-New York, Waxmann.

Jackson R. (2004), Rethinking religious education and plurality: issues in diversity andpedagogy. London, Routledge-Falmer.

Jackson R. (2014), The development and dissemination of Council of Europe policy on education about religions and non-religious convictions. "Journal of Beliefs and Values", 35(2). 
KittelmannFlensner K. (2015), Religious education in contemporary pluralistic Sweden. Göteborg, Göteborgs Universitet.

Klus-Stańska D. (2002), Konstruowanie wiedzy w szkole. Olsztyn, Wydawnictwo UWM.

Klus-Stańska D. (2008), Mitologia transmisji wiedzy, czyli o konieczności szukania alternatyw dlaszkoty, która amputuje rozum. „Problemy Wczesnej Edukacji”, 2(8).

KEP (Konferencja Episkopatu Polski) (2010), Podstawa programowa katechezy Kościoła katolickiego w Polsce. Kraków, WAM.

KEP (Konferencja Episkopatu Polski) (2018), Podstawa programowa katechezy Kościoła katolickiego w Polsce. Częstochowa, Edycja Świętego Pawła.

Lgr 62 (1962), Läroplan för grundskolan. Stockholm, Skolöverstyrelsen.

Lgr 69 (1969), Läroplan för grundskolan. 1, Allmän del. Stockholm, Utbildningsförlaget.

Lgr 80 (1980), Läroplan för grundskolan. Stockholm, Liber Läromedel/Utbildningsförlaget.

Lipman M., Sharp A.M., Oscanyan F.S. (1997), Filozofia w szkole. Warszawa, CODN.

Lpo 94(1994), Kursplaner för grundskolan. Stockholm, Utbildnings departementet.

Marek Z. (2017), Edukacja religijna w poszukiwaniu odpowiedzi na egzystencjalne pytania człowieka. „Paedagogia Christiana”, 2(40).

Mąkosa P. (2009), Katecheza młodzieży gimnazjalnej w Polsce. Stan aktualny i perspektywy rozwoju. Lublin, KUL.

Mąkosa P. (2011), Współczesne ujęcia nauczania religii w europejskim szkolnictwie publicznym. „Roczniki Pastoralno-Katechetyczne”, 3(58).

Pajer F. (1992), Nauczanie religii w europejskich systemach oświatowych. „Przegląd Powszechny”, 6.

Risenfors S. (2018), Liberal Muslim, Atheist Hindu and born-again christian identifications in relation to religion among three upper secondary students with experiences connected to migration. W: J. Ristiniemi, G. Skeie, K. Sporre (eds.), Challenging life existential questions as a resource for education. Münster-New York, Waxmann.

Sauer R. (2000), Religionsunterricht in Europa. W: H. Noormann, U. Becker, B. Trocholepczy (Hrsg.), Ökumenisches Arbeitsbuch Religionspädagogik. Stuttgart, Kohlhammer.

Sterkens C. (2001), Interreligious learning. The problem of interreligious dialogue in primary education. Leiden, Brill.

Stern E. (1957), Kind, Krankheit und Tod. München, E. Reinhardt.

Szczepska-Pustkowska M. (2008), Dziecięce filozofowanie (i filozofowanie z dziećmi) jako zasada pracy z uczniem. „Kwartalnik Pedagogiczny”, 1(207).

Śliwerski B. (2010), Czy możliwy jest w szkole dialog? „Paedagogia Christiana”, 1(25).

Tonåringen och livsfrågorna: elevattityder och undervisningen i livsåskådning och etik på grundskolans högstadium: elevundersökningar och metodiska förslag av en arbetsgrupp inom skolöverstyrelsen (1969), Stockholm, SÖ-förlaget.

Wright A. (2004), Religion, education and post-modernity. London, Routledge-Falmer.

Wright A. (2008), Contextual religious education and the actuality of religions. „British Journal of Religious Education”, 30. 